\title{
Emotional intelligence as a psychological resource and the features of its development in intellectually gifted school students
}

\author{
Liudmila I. Larionova ${ }^{1}$, Vyacheslav Petrov ${ }^{2}$, Polina V. Smirnova ${ }^{1 *}$, Oleg M. Zverev ${ }^{3}$, and \\ Maria Karaivanova ${ }^{4}$ \\ ${ }^{1}$ Moscow City University, Institute of Pedagogics and Psychology of Education, Department of \\ Psychology, Moscow, Russia \\ ${ }^{2}$ Irkutsk State University, Pedagogical Institute, Department of Psychodiagnostics and Practical \\ Psychology, Irkutsk, Russia \\ ${ }^{3}$ Moscow City University, Institute of Natural Sciences and Sports Technologies, Department of \\ Physical Education and Life Safety, Moscow, Russia \\ ${ }^{4}$ Academy of Music, Dance, Fine Arts of the Republic of Bulgaria, Plovdiv, Bulgaria
}

\begin{abstract}
The article touches upon the relevant problems of modern psychological and pedagogical science: support for and development of gifted school students, psychological resources of personality, and emotional intelligence. At present, the problem of the features of emotional intelligence development in gifted students is theoretically and empirically underexplored within the framework of the resource approach. The goal of the study is to research the features of the development of emotional intelligence as a psychological resource in gifted adolescent school students. The following methods were used: emotional intelligence questionnaire, resilience test, D. Raven's Progressive Matrix Scale; methods of mathematical statistics (analysis of variation, correlation analysis, etc.). The first part of the article presents an overview of studies on the problem of psychological resources and emotional intelligence, the current state of research in these fields is outlined, and the understudies issues and prospects for further studies are indicated. The empirical part presents the study results, the analysis of which reveals the specific features of emotional intelligence development in gifted adolescents compared to regular students. The obtained data indicate certain problems associated with the underdevelopment of emotional intelligence and its components in gifted adolescents which calls for further research and consideration in practical work with gifted students. The provided results of correlation analysis demonstrate a statistically significant association between the indicators of emotional intelligence and resilience. The obtained results point to the need for further study of the specifics of emotional intelligence and the opportunities for its development in gifted and non-gifted school students.
\end{abstract}

Keywords: giftedness, emotional intelligence, psychological resources.

\footnotetext{
*Corresponding author: polina_frolova@hotmail.com
} 


\section{Introduction}

One of the most significant and relevant problems faced by modern education is the need to identify, support, and provide psychological and pedagogical assistance to gifted students whose personalities and abilities are considered as an important factor in the development of society and its economic, social, scientific, and cultural potential. Of importance is creating the necessary conditions (external resources) for the development of a gifted person and revealing their potential, as well as searching for the internal psychological resources the presence and development of which allow the subject to unlock their potential and contribute to their personal and social realization.

In recent years, foreign and Russian psychological science has been showing great interest in the problem of internal psychological resources of personality. Scientific literature examines various resources including psychological, personality, intellectual, cognitive, regulatory resources, coping resources, stress resistance resources, etc. The problem of intellectual resources is examined by us in greater detail in a previous article [1].

In this study, we focus on examining emotional intelligence that can be characterized as a universal psychological resource mediating a person's success in a wide range of activities.

An important contribution to the study of emotional intelligence was made by [2-4]. Various practical and theoretical problems of emotional intelligence are examined in the works of C. Weissbach and U. Dax [5], G.G. Garskov [6], I.N. Andreev [7], D.V. Liusin [8], E.L. Nosenko and N.V. Kovriga [9], V.S. Iurkevich [10], I.N Meshcheriakova [11], and others.

Russian experience in the study of emotional intelligence is summarized by S. Shabanov and A. Aleshina [12]. The sphere of studies on the problem of emotional intelligence in psychological and pedagogical literature has been expanding in recent years: theoretical and methodological foundations of its study are examined, its age, gender, and social characteristics, as well as specifics in different professions and directions of training, are covered [13, 14]; its relationship with the effectiveness of the professional activity, leadership, giftedness [15], social success, aggression, etc, is explored. In our studies, we examined emotional intelligence as a factor (resource) mediating an individual's psychological well-being in difficult life conditions [16].

The analysis of sources on the problem of emotional intelligence shows that this topic is currently highly relevant, many studies note the important role and significance of emotional intelligence in achieving success in various spheres of activity [17]. Emotional intelligence is essentially viewed as an important resource of success [18-20], it is noted that the development of emotional intelligence has age and gender specifics; what is important in our view is the notion that emotional intelligence can and has to be intentionally developed [21$23]$ through the creation of a certain type of educational environment [24, 25].

At the same time, the issues associated with the patterns of age-related development of emotional intelligence and the study of its features in gifted students remain relatively underexplored. The problem of determining the effective means, approaches, and methods of its development maintains relevance.

The goal of the present study is to explore the features of the development of emotional intelligence as a psychological resource in gifted adolescent school students. We hypothesize that gifted students, compared with non-gifted students, show several specific features in the manifestation and development of emotional intelligence. We also assume that emotional intelligence can be considered a significant psychological resource. 


\section{Methods}

Methods deployed in the study include the "EMIN" emotional intelligence questionnaire [26], S. Maddi's Resilience Test [27], the "Raven's progressive matrix scale" method; methods of statistical processing and data analysis: analysis of variation, correlation analysis, Student's t-test.

The cumulative sample of the study consists of 249 respondents - students in grades 8-9 of lyceums and schools in Irkutsk including 151 lyceum students (showing the signs of intellectual giftedness) and 98 school students (lacking the signs of intellectual giftedness).

\section{Results}

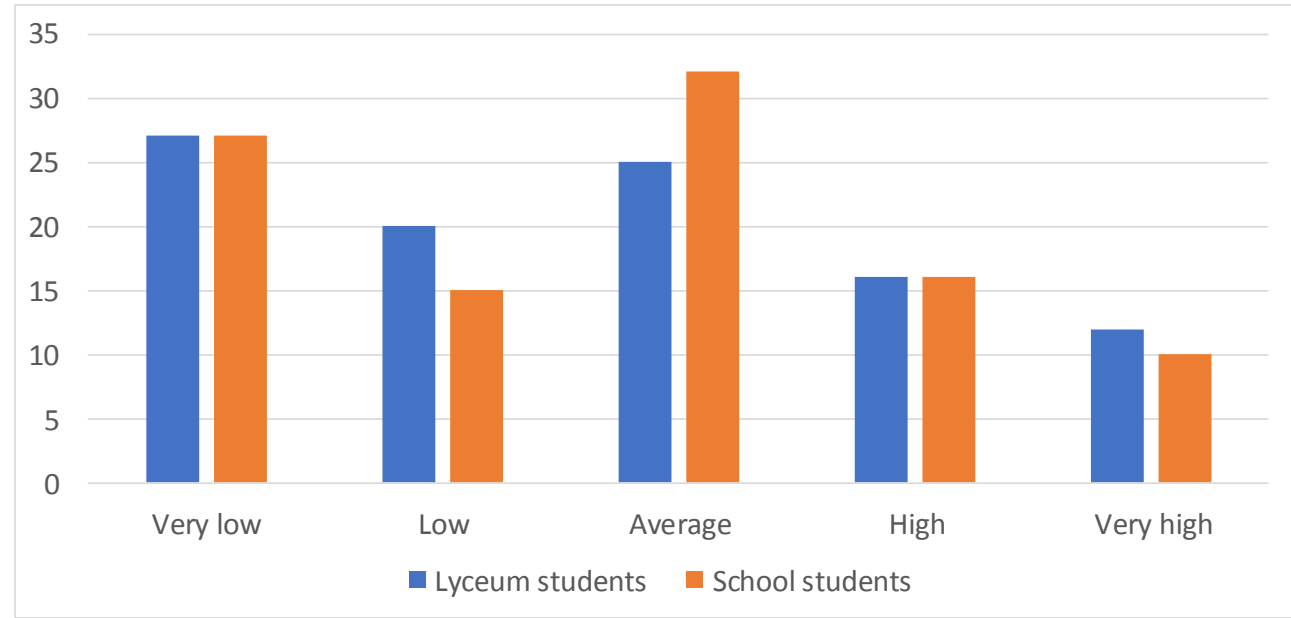

Fig. 1. Percentage distribution of students by the levels of manifestation of general emotional intelligence (the EmIn method).

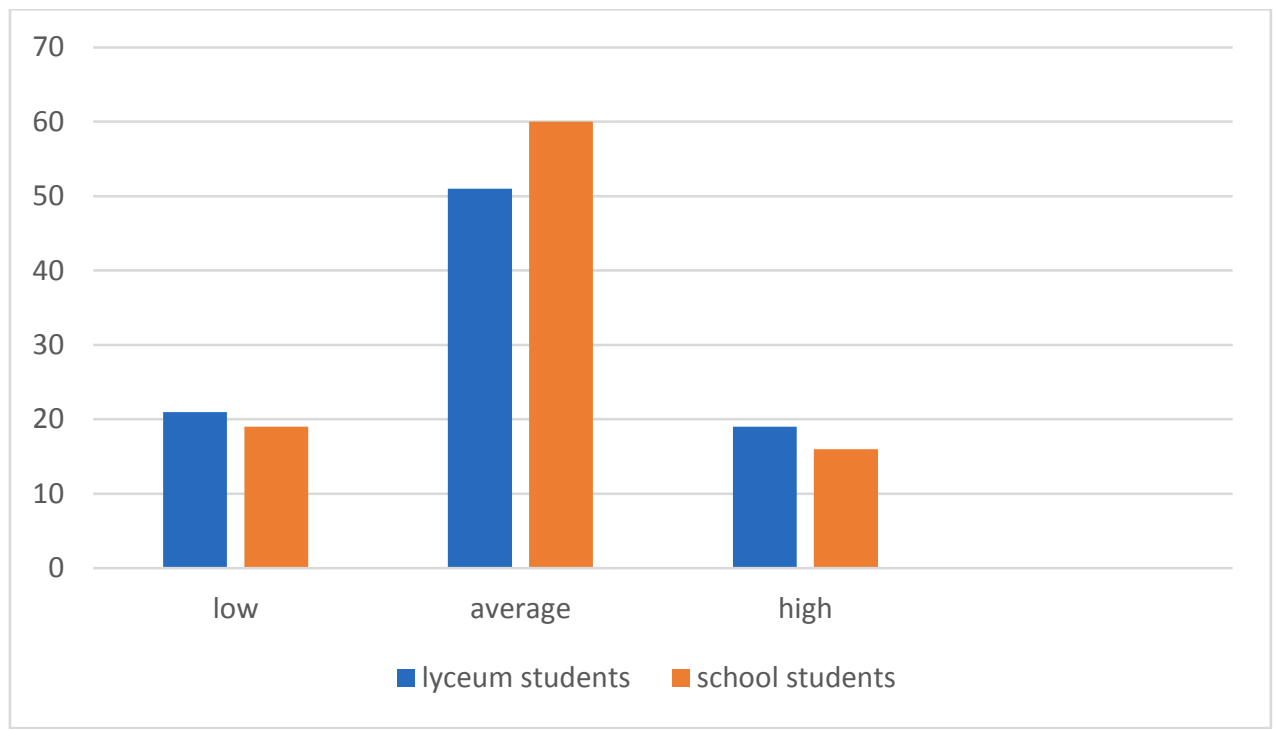

Fig. 2. Percentage distribution of students by the levels of manifestation of the overall indicator of resilience (S. Maddi's Resilience Test). 
Table 1. Results of a Pearson correlation analysis of the relationship between emotional intelligence and resilience in the total sample of students.

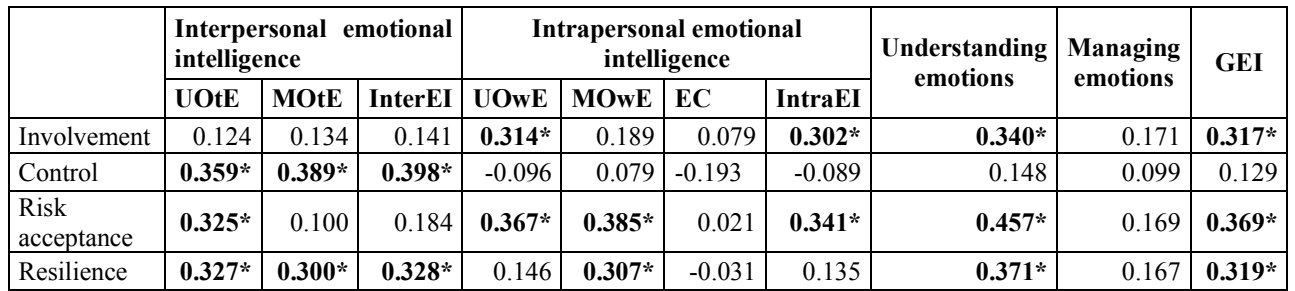

Note: * - statistical significance level $\mathrm{p} \leq 0.05$

UOtE - understanding others' emotions; MOtE - managing others' emotions; UOwE - understanding own emotions; MOwE - managing own emotions; EC - expression control; GEI - general emotional intelligence

\section{Discussion}

The signs of intellectual giftedness were assessed using the "Raven's Progressive Matrix Scale" method. The lyceum students expectedly show significantly higher results (mean in the lyceum group -117 points, in the school group -98 points, $t=3,26, p \leq 0.01$ ).

The analysis of results of the EmIn method (Fig. 1) shows that the compared groups demonstrate similar distributions by the levels of manifestation of general emotional intelligence - average and low values are predominant in most gifted and non-gifted students (the level of below average is found in $47 \%$ of lyceum students and $43 \%$ of school students, only a quarter of the respondents have emotional intelligence at the optimal, i.e. high, level). This result indicates the insufficient level of development of general emotional intelligence and its particular components in both sample groups and, accordingly, allows us to assume that almost half of the respondents potentially experience difficulties in interpersonal communication and successful self-realization. No reliable differences are found between the two groups.

A similar situation is observed regarding S. Maddi's Resilience Test (Fig. 2): no significant reliable differences are found between the two groups and the distributions are similar - the majority of respondents in both groups predominantly have the average level of resilience, high values are found only in 19\% of lyceum students and $16 \%$ of school students.

The results demonstrate that gifted students show no specific features in the development of emotional intelligence and resilience compared to regular students. The nuance is different: much in the lives of adolescents during this period depends on the quality of communication, the ability to communicate which implies the need for sufficiently high development of emotional intelligence and its components. As we can see, this indicator has not yet developed to a sufficient degree in most respondents. This can partially explain the fact that only a certain share of gifted students become quite successful and prosperous in the future, as well as the fact that success is also achieved by students lacking the signs of giftedness.

Since we consider resilience as an integral resource indicator that mediates the physical, psychological and social well-being of an individual, we conducted a correlation analysis (Pearson's r) to test the presence of a relationship between the studied indicators.

The results of the correlation analysis are presented in Table 1. The integral indices and most of the individual components of emotional intelligence and resilience significantly correlate with each other. From the content point of view, we can conclude on their semantic proximity. In other words, resilience and emotional intelligence functionally play the role of significant psychological resources which can provide for an individual's high adaptive capabilities, efficiency, effectiveness, and success in their activity. 


\section{Conclusion}

The conducted study supports the fundamental possibility of considering emotional intelligence and its components as significant psychological resources mediating the process of personality development in both intellectually gifted and non-gifted students. This issue requires further research in terms of empirical and theoretical verification of the obtained results.

\section{References}

1. L. I. Larionova, V. G. Petrov, D. Iu. Gorelysheva, Intellektualnye resursy psikhologicheskogo blagopoluchiia lichnosti v usloviiakh ekzistentsialnogo vyzova [Intellectual resources of psychological well-being under the conditions of the existential challenge], in A. L. Zhuravlev, M. A. Kholodnaia, P. A. Sabadosh (eds.), Sposobnosti i mentalnye resursy cheloveka v mire globalnykh peremen, 399-409 (Publishing House "Institute of Psychology of the Russian Academy of Sciences", Moscow, 2020). https://doi.org/10.38098/proc.2020.59.34.001

2. D. G. Goleman, Emotsionalnyi intellekt [Emotional intelligence] (AST, Moscow, 2009)

3. J. D. Mayer, P. Salovey, D. R. Caruso, Models of emotional intelligence, in R. Stenberg (Ed.), Handbook of intelligence, 396-420 (Cambridge University Press, N.Y., 2000)

4. R. Bar-On, The development of a concept of psychological well-being, Doctoral dissertation (Rhodes University, South Africa, 1988)

5. C. Weissbach, U. Dax, Emotsionalnyi intellekt [Emotional intelligence] (Lik Press, Moscow, 1998)

6. G. G. Garskova, Vvedenie poniatiia "emotsionalnyi intellekt" v psikhologicheskuiu teoriiu [Introduction of the concept of "emotional intelligence" into psychological theory], in Theses of the Scientific-Practical Conference "Ananiev Readings", 26 (Saint Petersburg: Saint Petersburg State University Publishing House, 1999)

7. I. N. Andreeva, Voprosy Psikhologii, 5, 63 (2007)

8. D.V. Liusin, Sovremennye predstavleniia ob emotsionalnom intellekte [Modern ideas about emotional intelligence], in D.V. Liusin, D.V. Ushakov (Eds.), Sotsialnyi intellekt: Teoriia, izmerenie, issledovaniia (Institute of Psychology of the Russian Academy of Sciences, Moscow, 2004)

9. E.L. Nosenko, N.V. Kovriga, Emotsionalnyi intellekt: kontseptualizatsiia fenomena, osnovnye funktsii [Emotional intelligence: the conceptualization of the phenomenon, its main functions] (Vysshaya shkola, Kostroma, 2003)

10. V.S. Iurkevich, Prakticheskaia Psikhologiia Obrazovaniia, 3(4), 4-10 (2012)

11. I.N. Meshcheriakova, Territory of Science, 9, 110-115 (2008)

12. S. Shabanov, A. Aleshina, Emotsionalnyi intellekt. Rossiiskaia praktika [Emotional intelligence. Russian practice] (MIF publishing house, Moscow, 2017)

13. K. M. Lee, M. K. Jones, S. X. Day, Learning and Individual Differences, 56(May), 151-158 (2017). https://doi.org/10.1016/j.lindif.2016.10.020.

14. 14 K. Bansal, Materialstoday: Proceedings, 37(2), 2934-2937 (2021). https://doi.org/10.1016/j.matpr.2020.08.701. 
15. M. Tang, C.H. Werner, Thinking Skills and Creativity, 24, 268-278 (2017). https://doi.org/10.1016/j.tsc.2017.04.001.

16. L. I. Larionova, V. G. Petrov, D. Iu. Gorelysheva, Psychology. Historical-critical Reviews and Current Researches, 9(2A), 21-31 (2020). https://doi.org/10.34670/AR.2020.73.68.003.

17. Y. S. Lee, S. H. Park, J. K. Kim, The Journal of the Korea Contents Association, 14(6), 229-240 (2014). https://doi.org/10.5392/JKCA.2014.14.06.229

18. J. E. Davidson, Genius, eminence, and giftedness, in Reference module in neuroscience and biobehavioral psychology. Encyclopedia of human behavior, 221-227 (2017). https://doi.org/10.1016/B978-0-12-809324-5.06435-X

19. R. I. Karpinski, A. M. Kinase, K. Nicole, A. Tetreault, T. B. Borowski, Intelligence, 66, 8-23 (2018). https://doi.org/10.1016/j.intell.2017.09.001.

20. U. Ogurlu, Personality and Individual Differences, 171, 110503 (2019)

21. S. E. Koohbanani, R. Dastjerdi, T. Vahidi, M-H. GhaniFar, Procedia - Soc Behav Sci., 84, 314-320 (2013). https://doi.org/10.1016/j.sbspro.2013.06.558.

22. T. R. Hayes, A. A. Petrov, P.B. Sederberg, Intelligence, 46, 1-14 (2015). https://doi.org/10.1016/j.intell.2014.10.005.

23. X. Ren, T. Wang, S. Sun, M. Deng, K. Schweizer, Intelligence, 66, 64-71 (2018). https://doi.org/10.1016/j.intell.2017.11.004.

24. A. Savenkov, P. Smirnova, N. Murodhodjaeva, EC Psychology and Psychiatry Articles 8.6, 707-713 (2019)

25. W. A. Yasvin, P. V. Smirnova, V. P. Peskov, I. S. Bulanova, SHS Web of Conferences 79, 01019 (2020). https://doi.org/10.1051/shsconf/20207901019.

26. D.V. Liusin, Oprosnik na emotsionalnyi intellekt EmIn: novye psikhometricheskie dannye [The EmIn emotional intelligence questionnaire: new psychometric data], in D.V. Liusin, D.V. Ushakov (Eds.), Sotsialnyi i emotsionalnyi intellekt: ot modelei k izmereniiam [Social and emotional intelligence: from processes to measurements], 264-278 (Institute of Psychology of the Russian Academy of Sciences, Moscow, 2009)

27. D.A. Leontiev, E.I. Rasskazova, Test zhiznestoikosti [Resilience test] (Smysl, Moscow, 2006) 